\title{
Mannose supplementation in PMM2-CDG
}

\author{
Roman Taday ${ }^{\dagger}$, Julien H. Park ${ }^{\dagger}$, Marianne Grüneberg, Ingrid DuChesne, Janine Reunert and \\ Thorsten Marquardt ${ }^{*}$ (i)
}

\begin{abstract}
In this response to the letter by Witters et al., we refer to the authors' arguments regarding spontaneous enhancement of glycosylation and the claim, that mannose has no place in the treatment of PMM2-CDG. Our paper "Dietary mannose supplementation in phosphomannomutase 2 deficiency (PMM2-CDG)" has shown that further investigation of mannose in PMM2-CDG is worthwhile alongside other treatment options and should not be dismissed off-hand without the willingness to prove or disprove it in controlled prospective clinical trials.
\end{abstract}

Keywords: PMM2, Congenital disorder of glycosylation, Mannose, Galactose, Therapy

The letter by Witters et al. relates to our recent publication on long-term mannose supplementation, a paper that did not summarize data of a prospective clinical study but analyzed data obtained by long-term care for PMM2 patients [1, 2]. Many of their arguments had already been discussed in our paper and our response is lined out in the following addresses the critical points.

\section{Improvement of glycosylation and biochemical variables}

The letter by Witters et al. regarding our publication focuses on the fact that glycosylation in PMM2-patients may improve spontaneoulsy over time. This is well known, not disputed, and has been cited throughout our study.

In their letter, the authors present the development of transferrin glycosylation in a cohort of 37 patients with somewhat limited data of 3 individual measurements per patient in average. In contrast, the subjects of our study underwent transferrin glycosylation analysis up to 40 times during the follow-up period. The use of the di- and monoglycosylated transferrin ratio limits the

*Correspondence: marquat@uni-muenster.de

†'Roman Taday and Julien H. Park contributed equally to this work. Department of General Pediatrics, University Children's Hospital Münster, Albert-Schweitzer-Campus 1, 48149 Münster, Germany comparability of the studies since it does not take aglycosylated (i.e. asialo-) transferrin into account.

Two observations are critical in the interpretation of the data we have presented but have not been addressed by Witters et al.:

1. Following long-term interruption of mannose supplementation, transferrin glycosylation returned to pre-treatment levels as demonstrated in Fig. 1C of the original publication. This was mirrored clinically by nerve conduction velocities improving during supplementation and decreasing again following discontinuation.

2. The observed improvement of glycosylation was ageindependent.

\section{Clinical improvement}

In our paper, we state that due to the highly variable clinical manifestations and course as well as laboratory abnormalities, it is not easy to make predictions about the outcome or natural history of an individual patient a priori or to define relevant end points for clinical trials. Many arguments raised in the letter do not respect the fact that our study summarizes historical data from clinical practice and not from a prospective study. Regarding the deterioration of normalized nerve conduction original author(s) and the source, provide a link to the Creative Commons licence, and indicate if changes were made. The images or other third party material in this article are included in the article's Creative Commons licence, unless indicated otherwise in a credit line to the material. If material is not included in the article's Creative Commons licence and your intended use is not permitted by statutory regulation or exceeds the permitted use, you will need to obtain permission directly from the copyright holder. To view a copy of this licence, visit http://creativecommons.org/licenses/by/4.0/. The Creative Commons Public Domain Dedication waiver (http://creativeco mmons.org/publicdomain/zero/1.0/) applies to the data made available in this article, unless otherwise stated in a credit line to the data. 
velocity of our index-patient under mannose, Witters et al. do not discuss that deterioration happened in a temporal relation to discontinuation of mannose supplementation at the age of nine years. We equally conclude double-blind randomized controlled trials taking into account the natural history of the disease will be needed to validate the current findings.

\section{Role of mannose in PMM2-CDG}

Given the efficacy of mannose supplementation in cell culture $[4,5]$ as well as in a murine model [6] in addition to our clinical findings, we are very concerned about the implied idea that studying mannose in PMM2-CDG might be a futile endeavor and that other treatment options might be the only ones worth pursuing in the future. Dismissing ideas off-hand without the willingness to prove or disprove them in a clinical trial, is not what clinical science should be like. As the authors state themselves, there are more than 900 patients worldwide providing a basis for many different treatment trials. Indeed, even non-intuitive concepts such as D-galactose supplementation for PMM2-CDG, a disorder in which no hypogalactosylation has ever been found, have been explored [3].

Alternative therapeutic concepts put forward by the authors are hindered by their own limitations: while showing impressive improvement with regards to ataxia, acetazolamide is a purely symptomatic therapy targeting a single one of the multiple organ systems involved in PMM2-CDG [7]. Mannose derivates such as Man-1-P are in theory intriguing since they might bypass the enzyme defect. In reality, there are currently no stable, non-toxic, and easily transportable compounds for lifelong therapy [8] in addition to the limitation that these compounds are likely not able to cross the blood-brain barrier (BBB).

In contrast, small molecule PMM2 activators such as chaperones are in principle able to pass the BBB but are currently limited to specific mutations, [9] as demonstrated by the aldolase inhibitor epalrestat [10]. MPI-inhibitors have limited access to some tissue compartments or are effective only in areas with a favorable PMM2: MPI-ratio [8].

Mannose ensures a half-life suitable for oral continuous therapy, as well as an all-encompassing accessibility to different organ systems (including the blood-brain barrier) [11]. A goal of therapy for PMM2-deficient patients might be to increase the flux of metabolic precursors into the depleted glycosylation pathways. Combinations of dietary mannose with other mentioned coadministratives may be viable options for establishing appropriate continuous therapy. Our paper gives sufficient evidence that mannose could be a cornerstone for clinically applicable treatment options for PMM2-CDG. Nevertheless, especially in these times, where truth is often difficult to determine, no treatment idea should be dismissed off-hand but all should be proven or disproven by welldesigned clinical trials.

The vivid discussion around potential therapies stresses the desperate need for improved treatment options for PMM2-CDG and indeed most glycosylation disorders. The ongoing efforts of multiple groups to advance the treatment for affected individuals are encouraging and offer the potential to impact patient care substantially, as does the impressive involvement of patient organizations. We agree that natural history studies and novel biomarkers will be key to design the urgently needed trials to validate therapeutic concepts for CDG and would like to stress the importance to consider all available options to improve treatment of these devastating diseases.

\section{Acknowledgements}

Not applicable.

\section{Authors' contributions}

RT and JHP drafted the initial version of the manuscript. All authors read and approved the final manuscript.

\section{Funding}

Not applicable.

Availability of data and materials

Not applicable.

\section{Declarations}

Ethics approval and consent to participate

Not applicable.

\section{Consent for publication}

Not applicable.

\section{Competing interests}

The authors declare that they have no competing interests.

Received: 22 April 2021 Accepted: 27 July 2021

Published online: 11 August 2021

References

1. Witters P, Edmondson AC, Lam C, Johnsen C, Patterson MC, Raymond KM, et al. Spontaneous improvement of carbohydrate-deficient transferrin in PMM2-CDG without mannose observed in CDG natural history study. Orphanet J Rare Dis. 2021;16(1):102.

2. Taday R, Grüneberg M, DuChesne I, Reunert J, Marquardt T. Dietary mannose supplementation in phosphomannomutase 2 deficiency (PMM2CDG). Orphanet J Rare Dis. 2020;15(1):258.

3. Witters P, Andersson H, Jaeken J, Tseng L, van Karnebeek CDM, Lefeber DJ, et al. D-galactose supplementation in individuals with PMM2-CDG: results of a multicenter, open label, prospective pilot clinical trial. Orphanet J Rare Dis. 2021;16(1):138.

4. Panneerselvam K, Freeze HH. Mannose corrects altered N-glycosylation in carbohydrate-deficient glycoprotein syndrome fibroblasts. J Clin Invest. 1996;97(6):1478-87.

5. Rush JS, Panneerselvam K, Waechter CJ, Freeze HH. Mannose supplementation corrects GDP-mannose deficiency in cultured fibroblasts from some patients with Congenital Disorders of Glycosylation (CDG). Glycobiology. 2000;10(8):829-35. 
6. Schneider A, Thiel C, Rindermann J, DeRossi C, Popovici D, Hoffmann GF et al. Successful prenatal mannose treatment for congenital disorder of glycosylation-la in mice. Nat Med. 2012;18(1):71-3.

7. Martinez-Monseny AF, Bolasell M, Callejon-Poo L, Cuadras D, Freniche V, Itzep DC, et al. AZATAX: Acetazolamide safety and efficacy in cerebellar syndrome in PMM2 congenital disorder of glycosylation (PMM2-CDG). Ann Neurol. 2019;85(5):740-51.

8. Freeze HH. Towards a therapy for phosphomannomutase 2 deficiency, the defect in CDG-la patients. Biochim Biophys Acta. 2009;1792(9):835-40.

9. Yuste-Checa P, Brasil S, Gamez A, Underhaug J, Desviat LR, Ugarte M, et al. Pharmacological chaperoning: a potential treatment for PMM2-CDG. Hum Mutat. 2016:38:160-8.
10. Iyer S, Sam FS, DiPrimio N, Preston G, Verheijen J, Murthy K, et al. Repurposing the aldose reductase inhibitor and diabetic neuropathy drug epalrestat for the congenital disorder of glycosylation PMM2-CDG. Dis Model Mech. 2019;12(11):dmm040584.

11. Alton G, Kjaergaard S, Etchison JR, Skovby F, Freeze HH. Oral ingestion of mannose elevates blood mannose levels: a first step toward a potential therapy for carbohydrate-deficient glycoprotein syndrome type I. Biochem Mol Med. 1997;60(2):127-33.

\section{Publisher's Note}

Springer Nature remains neutral with regard to jurisdictional claims in published maps and institutional affiliations.
Ready to submit your research? Choose BMC and benefit from:

- fast, convenient online submission

- thorough peer review by experienced researchers in your field

- rapid publication on acceptance

- support for research data, including large and complex data types

- gold Open Access which fosters wider collaboration and increased citations

- maximum visibility for your research: over 100M website views per year

At BMC, research is always in progress.

Learn more biomedcentral.com/submissions 